\title{
Resolving Issues In Innovative Graduate Degree Programs: The Metropolitan State University Doctor Of Business Administration Experience
}

\author{
Tim Delmont, Ph.D., Metropolitan State University, USA
}

\begin{abstract}
Applied Master's Degree and doctoral programs have been criticized widely for their lack of relevance, rigor and quality. New graduate degree programs have responded to these criticisms by implementing innovative academic policies, program curriculum, and student services. A case study of the Metropolitan State University Doctor of Business Administration (DBA) program highlights effective innovations for resolving key issues facing applied doctoral programs.
\end{abstract}

Keywords: Professional doctoral degree programs; applied doctor of business administration degree program; innovative graduate degree programs

\section{INTRODUCTION}

C $\mathrm{n}$ the past two decades, applied professional doctoral degree programs have emerged in response to market demand in developed countries. Many have been criticized as lacking in relevance, rigor, and quality. However, newer programs, especially in business and educational administration, are characterized by innovative professional education practices typically drawn from both professional Master's Degree and Ph.D. programs. In particular, innovations in academic policies, program curriculum, and student services address longstanding criticisms of applied, graduate degree programs. In this paper, selected issues in the development of graduate degree programs, and effective responses to them, are examined through a case study of the new Doctor of Business Administration (DBA) degree program at Metropolitan State University.

\section{STUDENT ACCESS}

While demand for access to doctoral degree programs varies across disciplines, it is especially high in business administration. Recent professional association and government labor market studies document the need for doctoral-trained faculty and practitioners in business disciplines, especially in accounting and financial management (The Association to Advance Collegiate Schools of Business, 2002, American Accounting Association, 2002, Minnesota Department of Employment and Economic Development, 2008). Available faculty positions in business schools remain unfilled and the development of "executive scholar" management positions, called for by the profession, has slowed (The Association to Advance Collegiate Schools of Business, 2003, Bisoux, 2009). Access to traditional business doctoral programs is limited because admission competition for small numbers of slots is intense, most programs require full time participation, most are delivered during traditional work week hours, and most are lead by faculty instructors and dissertation advisors whose numbers are limited by recent funding constraints, especially in public research universities, and whose workloads are increasing. For many working professionals, access to traditional doctoral business programs is nearly impossible.

In the Metropolitan State DBA program, the response to this student access issue has been to develop 1) balanced admission criteria and standards (criteria consisting of GMAT scores, Master's Degree GPA, years of professional work experience, and achievements in professional work, all weighted equally) and 2) deliver a part 
time, "hybrid" program, with classes offered on Saturdays and web work in between. This model, developed in response also to local focus group opinions of prospective students and professional practitioners, reflects the flexible delivery of online programming characteristic of many professional Master's Degree and some doctoral degree programs.

\section{CURRICULUM RELEVANCE AND QUALITY}

Professional doctoral degree programs have been criticized for their inconsistent and unclear expectations, lack of relevant course content, and lack of rigorous standards (Barnett, 2010, Nobel, 1994). Some schools offer a generalized curriculum, others a rich but not necessarily integrated set of courses and still others provide significant opportunities for specialized study. Developing a model of quality equally useful for prospective faculty or professional practitioners or both has been a challenge.

Metropolitan State has implemented a number of approaches for ensuring relevance in the DBA curriculum. DBA faculty created an integrated, generalized curriculum for all students, with elective courses in academic and professional skills areas, such as teaching, management consulting, and advanced leadership, to address the varying career aspirations of its students. Students may also participate without charge in all internal professional development workshops offered to Metropolitan State faculty, which frequently address teachingrelated topics, such as online learning, curriculum development, and student learner outcomes assessment as well as topics on administration and leadership. This is an option not typically available to students in professional doctoral programs.

The applied curriculum and pedagogy of the DBA program are based significantly on adult learning principles, a characteristic of many professional Masters Degree and doctoral programs (Marie, Adams, and Garn, 2010). In DBA courses, emphasis has been placed on specific adult learning principles, such as active and problembased learning approaches, job-related course assignments, and use of on-line learning, with clear guidelines on group discussion assignments. In course evaluations, DBA students have indicated that they value this emphasis, finding it a useful bridge between theory and practice.

Similarly, Metropolitan State uses many approaches to promote course quality. University policy requires that all DBA course syllabi include course objectives, learner outcomes, description of course assignments and deadlines, grading criteria, and relevant academic policies. To strengthen standards, DBA faculty prepared criteria to distinguish doctoral from Master's Degree courses, requiring each course developer to include activities such as "the synthesis and evaluation of key research findings in the field, the development of an independent framework of ideas from existing bodies of work, and a seminar format requiring regular presentation of course presentations and student papers" (College of Management, January, 2009).

To ensure relevance and quality in course content, all course syllabi are examined and approved by multiple faculty committees in the College of Management and the University. All course developers are holders of doctorates with significant professional work experience in the fields in which they teach, many with more than 20 years of practitioner experience prior to moving into full time faculty positions. They are knowledgeable about developing quality courses with an applied focus.

\section{COMPLETION OF THE DISSERTATION}

Evidence suggests that completion of the dissertation is often problematic for many doctoral students. Problems include unclear research process expectations, difficulty in conceptualizing a dissertation project, lack of skills in implementing research methodology, and inconsistent or ineffective advising by faculty (Noble, 2010, Normer, 2010).

The "scholarship of application", proposed by Ernest Boyer, is the philosophy of the DBA research process. Its focus is on the scholarly investigation and application of knowledge to the needs and problems of the larger community (Boyer, 1990). Its goal is to narrow the gap between theory and practice. While some Ph.D. programs share a similar philosophy, most do not. This philosophy drives the structure and policies of DBA dissertation projects. 
In the DBA program, students complete three research courses in their first five semesters of "core" study (the core consisting of the first six semesters of study). In the first semester of study, they complete a research course whose product is an initial prospectus - a mini version of the dissertation proposal - consisting of a topic, literature search, and identification of research methodology. The course also introduces students to qualitative research methodologies. This early introduction to the research process helps students conceptualize a practical dissertation project and offset anxieties many feel - at mid career - about engaging in doctoral-level research. The second research course covers quantitative research methodologies. In the third research course, students produce a fully developed research proposal consisting of a topic, literature search, and methodology that constitutes a draft of the first three chapters of their dissertations.

Through participation in research courses both initially and sequentially during the first two years of doctoral study, students learn the objectives and expectations of DBA doctoral research as well as select the research tools and develop the skills they will use in their inquiry. Upon completion of their core courses and a comprehensive examination, they are poised to begin dissertation data gathering and subsequent drafting of study chapters. This process of "embedding" research courses in the core curriculum, while not typical of professional doctoral programs, is an innovative feature of the DBA program.

In their first two years of study, students are advised informally by the DBA Program Director, by DBA course instructors, and by other DBA faculty whom they contact. Under consideration, is the hiring of a "dissertation consultant", a doctoral-trained community faculty member with research expertise who will be available free of charge to students for one-on-one consultations about their dissertation projects. The dissertation advisor - the chair of the dissertation subcommittee - will be assigned to the DBA student at the end of the fifth semester, the semester in which the preliminary dissertation proposal has been developed by the student. A new University compensation policy - the first of its kind in the University - has been passed which provides DBA faculty with pay for DBA course instruction and dissertation advising matching that for all other faculty workload responsibilities, ensuring an appropriate financial incentive to attract capable faculty to the DBA program. The initiatives described above enhance the likelihood of successful completion of dissertation studies by DBA students.

\section{DROP OUT TRENDS AND RATES OF PROGRESS}

Many students drop out of doctoral programs in the first two years of study, with a considerable number also leaving at the "ABD" - all but dissertation - stage. Dropout rates are significant, from over 30\% to over 70\%, depending upon the discipline, with an average of over 50\% across all fields (Bowen and Rudenstein, 1992). Contributing factors to dropping out include many dealing with completion of the dissertation (e.g., unclear research process expectations, difficulty in conceptualizing a dissertation project, lack of skill in implementing research methodology, inconsistent advising and support by faculty) as well as the lack of perceived collegiality or community, insufficient financial resources, and work-life balance challenges. Slow progress toward completion of the doctoral program - taking many more years than anticipated at additional costs to students - can be prompted by these same factors.

As mentioned above, Metropolitan State has implemented pro-active research process policies and procedures as well as multiple advising services to mitigate against drop out and slow rate of progress possibilities. Other efforts, consistent with those of effective professional graduate programs, are being made to "socialize" students and build a sense of community, factors which tend to strengthen student commitment to a program (Ehrenberg and Kuh, 2009) Student participation in the DBA cohort program model, in which all students are enrolled in the same classes, is building positive relationships through cooperative completion of classroom and web assignments, often involving pairs, trios, or groups of students.

Students participate in a New Student Orientation in which they share "bios" of themselves with each other, meet with DBA faculty and administrators, visit over dinner with the University president, and complete workshops on using research methodologies, library resources, and web-based tools for course and research purposes. Students are also photographed individually and as a group, and prepare written bios which are included, with their pictures, in a class directory, distributed at the start of the first semester of study. In multiple evaluations of their courses and of the Orientation, students indicated that these efforts have built positive relationships and a sense of community 
within the DBA program. They also praised DBA faculty for their accessibility, responsiveness, and support. Regular social gatherings for DBA students and faculty and the creation of a DBA Student Advisory Committee, offering advice to faculty on policy matters, further support the development of a "community of scholars" experience.

Since DBA students are mid career, full time, paid professional employees, they do not generally face program funding challenges experienced by many younger doctoral students, who finance their education through teaching or research assistantships - often modest in nature. DBA students who are members of faculty unions in Minnesota public higher education institutions are eligible for various tuition and fee waivers, a significant fringe benefit of employment. These circumstances lessen the likelihood of student drop outs for financial reasons.

Work-life balance issues are significant for Metropolitan State DBA students. In two fall semesters of study, they are enrolled in two doctoral courses while working full time professionally. In evaluation surveys and informal conversations, students have generally indicated that their fall course schedule is "demanding but doable". A subset of students have said that they "barely manage to hold their heads above water" (College of Management, 2010).

As with other adults, DBA students have professional work obligations and family and community commitments. To help them manage academic and outside commitments, faculty selected the hybrid program model, requiring attendance at classroom sessions on an alternate week basis. Similarly, the selection of Saturdayonly classes have helped many students, especially those who are CPA's with heavy evening workloads during tax season, to better manage their schedules. The emphasis on applying course assignments to professional work responsibilities has also allowed academic and work roles to overlap. As a three year program (students enter with an MBA or management-related degree), the DBA is structured to be a time-limited experience - something not true of many other professional doctoral programs. While work-life balance issues are prevalent, students have indicated that many DBA initiatives are helping them cope in an acceptable fashion.

\section{CONCLUSION}

Key issues in the development and delivery of professional doctoral degree programs include ensuring student access, curriculum relevance and quality, completion of the doctoral dissertation, and managing drop out and time-to-completion issues. In this paper, effective responses for resolving these issues in Metropolitan State's applied DBA program have been described. Assessment of these responses will continue as new cohorts enroll in the program.

\section{AUTHOR INFORMATION}

Timothy J. Delmont is Assistant Professor of Management, the Director of the Doctor of Business Administration (DBA ) program, and Director of Graduate Studies in the College of Management, Metropolitan State University (Minneapolis, MN). He formerly was the Director of and a faculty member in the Masters of Management degree program of St. Mary's University (MN), and the Director of the Center for Human Resource Development, a training, development, and consulting office for the University of Minnesota higher education system. He has wide experience in higher education as a management consultant and speaker on strategic planning and graduate program development.

\section{REFERENCES}

1. Barnett, Bruce G. (2010). Forward. In Jean-Marie Gaetene \& Anthony H. Normore (Eds.), Educational Leadership Preparation (pp.xi-xiii). New York: Palgrave Macmillan.

2. Bisouux, Tricia. (2009, March/April). Solving the Doctoral Dilemma. BizEd, 24-31.

3. Bowen, William G., and Rudenstine, Neil. (1992). In Pursuit of the PhD. Princeton, New Jersey: Princeton University Press.

4. Boyer, Ernest L. (1990). Scholarship Reconsidered: Priorities of the Professoriate. Princeton, New Jersey: The Carnegie Foundation for the Advancement of Teaching. 
5. College of Management. (2009). Criteria for DBA Course Evaluation. Minneapolis: Metropolitan State University.

6. College of Management. (2010). Initial Assessment of the DBA Program. Minneapolis: Metropolitan State University.

7. Ehrenberg, Ronald G., and Kuh, Charlotte V. (Eds.). (2009). Doctoral Education and the Faculty of the Future. Ithaca and London: Cornell University Press.

8. Gaetane, Jean-Marie, Adams, Curtis M., and Garn, Greg, 2010. Renewing the Ed.D.: A University K-12 Partnership to Prepare School Leaders. In Jean-Marie Gaetene \& Anthony Normore (Eds.), Educational Leadership Preparation (pp. 99-109). New York: Palgrave MacMillan.

9. Management Education at Risk. (2002). St. Louis, MO: The Association to Advance Collegiate Schools of Business International.

10. Minnesota Department of Employment and Economic Development. (2008). www.deed.state.mn.us/Imi/tools/projections/Results.aspx?database.

11. Noble, Keith Allan. (1994). Changing Doctoral Degrees: An International Perspective. Buckingham, England: The Society for Research into Higher Education \& Open University Press.

12. Normore, Anthony H. (2010). Historical Context of Graduate Programs. In Jean-Marie Gaetene \& Anthony Normore (Eds.), Educational Leadership Preparation (pp 7-31). New York: Palgrave Macmillan.

13. Supply and Demand for Accounting Ph.D. 's. (2005). Orlando, Florida: American Accounting Association.

14. Sustaining Scholarship in Business Schools. (2003). St. Louis, MO: The Association to Advance Collegiate Schools of Business International. 
NOTES 